\title{
Online Study Habits of Secondary Ashramic Students of West Bengal during Pandemic Situation
}

\author{
Anita Karmakar \\ State Aided College Teacher, Gandhi Centenary B.T. College Habra, North 24 Parganas, \\ 743268. Email: anitakarm12345@gmail.com
}

\begin{abstract}
:
Objective: The prime focus of the paper is to find the impact of online study habits on students from secondary ashramic of West Bengal during Pandemic. The paper studied the impact in two different localities i.e., north and south 24 Parganas. The study habits always has a remarkable influence on the student's engagement and learning experiences. Therefore, the present study will determine the impact of online study habits on students from secondary ashramic of West Bengal during Pandemic.
\end{abstract}

Methodology:_The study is Descriptive survey nature where stratified sampling techniques has adopted for selecting the respondents from the study area of West Bengal. The total number of respondents were 201. As a research instrument investigator used three different tools- three self-made questionnaire tools used for collecting responses from the respondents. First questionnaire deals with the dimensions of online engagement, second one deals with online learning experience and lastly with the dimension of online study habits. The data analyzed with the help of descriptive and inferential statistics using SPSS software.

Result: The findings of the study reveals that there is significant relationship between variables. It is found that both the localities of students does vary significantly in online engagement, online learning experience and online study habit. High positive correlation prevail between online engagement and online learning experience with $r=.873$.

Keywords: Online Study Habits, online engagement, online learning experience, Ashram schools, secondary students. Pandemic situation.

\section{Introduction}

The concept of ashram schools derived from the term "Ashram", which has its origins in ancient India. It was knew as the "Household of the teacher". In one sense, the guru and his wife provided care and support to the students that is conducive for their enrichment of personal life. The origin of the Ashram schools functioning initiated in the state of Gujarat is within the basic education or new coaching of Mohandas Karamchand Gandhi. The Kocharab Ashram and the castaway Ashram established by Mohandas Karamchand Gandhi in Gujarat are wonderful samples of this. The fundamentals of basic education within the ashram faculty have come back from these ashrams. Gandhiji's main objective behind establishing the ashram was to organize freedom fighters for the liberty struggle and to run constructive programs. Later, 
Mohandas Karamchand Gandhi additionally joined basic education with ashram life. The Ashram schools that are pass by State Governments are a vital tool to offer formal education to ST Offsprings. Within the Sixties, Ashram school started on experimental basis. Consistent with Dewey (1926) Education is a continuous process of experiencing and of revising or nonrevising experiences. It is the development of all those capacities in the individual, which enable him to control his environment and fulfill his possibilities' (Y.K.Singh, p.22). The pandemic has necessitated online teaching which has been imposed upon many for whom it was only unfamiliar, but also undesirable. As social distancing and lockdown became public policies to arrest the spread of this nefarious disease, traditional modes of education swapped for the more technology-intensive and nuanced online platforms.

According to a UNESCO report, 1.38 billion learners worldwide affected by national school closures initiated in the aftermath of COVID-19. Several experienced for the first time, the new online mode of education, while others with previous exposure to this field faced with fullfledged online exams and lectures for the first time. Online learning is a term that encompasses web-based teaching, e-learning, distributed learning, net-based learning, web-based training, cyber learning, virtual learning and internet-based learning (Urban and Wegen, 2000). A sharp divide is evident between urban-rural segments in resources available to avail online education services. Locations that are far from main urban areas or at considerable height from the mean sea level face poor network and connectivity. Students drawn in from various rural and periurban areas towards urban areas to receive education (Mahadev \& kumaran, 1998). Tasks undertaken by an online instructor are different from those of a traditional teacher. Face-toface interaction that a regular classroom offers is unavailable in an online session. Mere physical presence may suffice in a regular classroom. However, online model leaves the student with the added responsibility of having good preparedness levels, with a soundly functioning device, internet connectivity that allows for effective audiovisual reception and transmission. Therefore, significant impact of the changing education system falls on the students. Apart from disruption of academic calendar, career plans and potential job loss, students face several other problems due to the online system. One aspect of this pertains to the technicalities of online learning such as loss of interactivity, lack of access to study material, improper infrastructure etc. Loss of formal education through traditional methods will have to bridge by online methods to ensure continuity of growth in human capital potential. Home schooling may seem like another option. However, different students coming from different backgrounds will have unequal opportunities due to differences in family income, access to resources, parent's level of education, ability of guardians to devote time to teach their children. In a country like India where deprivation is rampant, this will heavily ostracize the marginalized sections. All these have actually affected the study habits of students. As due to lockdown, the residential students were send back to their home place and most of them devoid of such opportunities and privileges and as a result, it affected their performance. Schools adopted relevant technologies, prepared learning and staff resources, set systems and infrastructure, established new teaching protocols, and adjusted their curricula. However, the transition was smooth for some schools but rough for others. So the researcher through her investigation will highlight on the above-mentioned major issues. 


\subsection{Conceptual Framework}

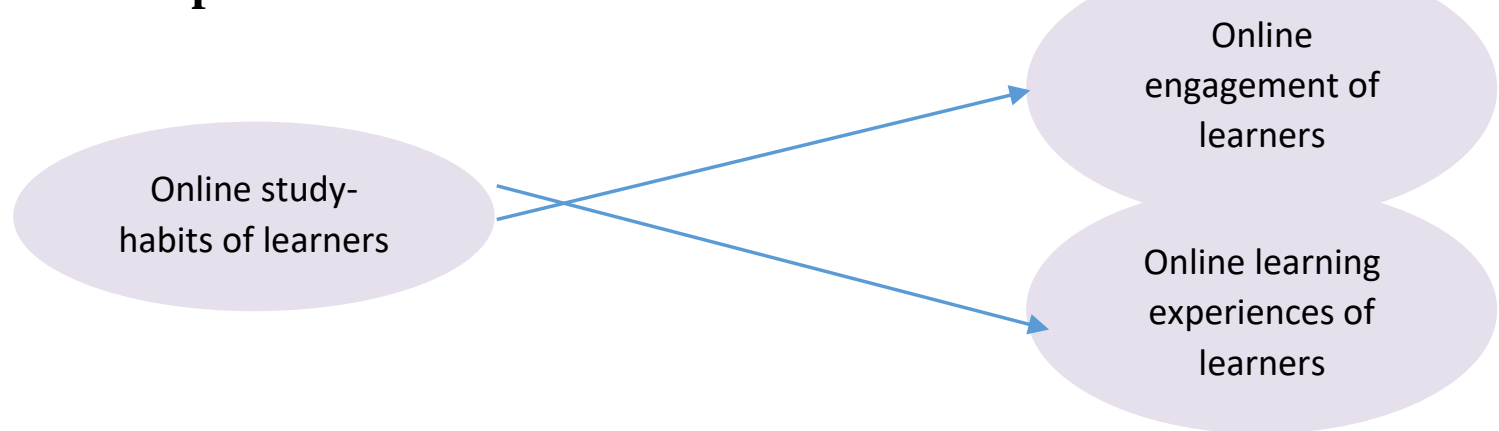

Figure 1: Showing the conceptual Framework

Source: Self-made by investigator

The online study habits of learners depends upon the online engagement i.e., engagement can be defined as a measure of a student's participation in the learning process. This includes their interaction and cooperation with the teacher and classmates. It also include learner teacher interaction, learner-learner interaction and content-learner interaction. These elements affects the online study habits of learners. Online Study habit is an action like, online reading, online taking notes, holding study groups, which the students perform regularly, and habitually in order to accomplish the task of learning. Study habits e described as effective or ineffective depending upon whether or not they serve the students well. Good study skills can increase your confidence, competence, and self-esteem. They can also reduce anxiety about tests and deadlines. By developing effective study skills, you may be able to cut down on the numbers of hours spend studying, leaving more time for other things in your life. Online learning experience includes structured course or learning experience delivered electronically; it can also include performance support content, clarification about project or assignment, facing technical issues, provision of on-demand access, use of gamification for learner engagement etc. Therefore, through the investigation the researcher tries to find out effect of online study habits of learners on the

\subsection{Need and Significance of Study}

The Information and communication technologies that have an effect on all spheres of life are also actively included in the education field. With the recent developments, using technology in education has become inevitable due to personal and social reasons (Usta, 2011). The period of Covid-19 pandemic has emerged as a sudden state of having limited opportunities. Face to face, education has stopped in this period for a long time. The global spread of Covid-19 affected more than 850 million students all around the world, and it caused the suspension of face-to-face education. Different countries have proposed several solutions in order to maintain the education process during the pandemic. Schools have had to change their curriculum, and many countries supported the online education practices soon after the pandemic. In other words, traditional education gave its way to online education practices. At least 96 countries have been motivated to access online libraries, TV broadcasts, instructions, sources, video lectures, and online channels. The general impact of online study habit on an online engagement and online learning experiences discovered in the study. Therefore, this will 
provide an opportunity to get a general overview of the online education, which practiced, and discussed intensively in pandemic scenario. Moreover, the general impact of online study habits on secondary ashramic students analyzed, considering different variables.

\subsection{Review of Literature}

- Fjelstul, J. (2006). The impact of online education on academic performance for LPGA teaching and club professionals. University of Central Florida. Suggested uses of this study include the future development of online review sessions for LPGA Class B and Apprentice written evaluations, with the goal of improving academic performances. Future research should include replication of the present study, but with a larger sample size. Future research should also involve Class B and Apprentice test takers and not be limited to first time test takers.

- Xu, D., \& Jaggars, S. S. (2013). The impact of online learning on students' course outcomes: Evidence from a large community and technical college system. _Using a large administrative dataset from a statewide system including 34 community and technical colleges, the authors employed an instrumental variable technique to estimate the impact of online versus face-toface course delivery on student course performance. The travel distance between each student's home and college campus served as an instrument for the likelihood of enrolling in an online section of a given course. In addition, college-by-course fixed effects controlled for withinand between-course selection bias. Analyses yield robust negative estimates for online learning in terms of both course persistence and course grade, contradicting the notion that there is no significant difference between online and face-to-face student outcomes — at least within the community college setting. Accordingly, both two-year and four-year colleges may wish to focus on evaluating and improving the quality of online coursework before engaging in further expansions of online learning.

- Nguyen, V. A. (2017). The impact of online learning activities on student learning outcome in blended learning course. Interactive activities are considered, in this study, include teacher - student interaction, student - student interaction, student - content interaction, and student - technology interaction. The undergraduate student participated in the blended learning course which using formative assessment to evaluate student learning outcomes by the combination of different learning activities through a learning management system. The quantitative results obtained when implementing learning analytics data from the system through using regression analysis showed that the students interact effectively with learning activities in the course have better results. Quantitative analytical results indicate that student - student interaction has a greater impact on student learning outcomes.

- Salamat, L., Ahmad, G., Bakht, M. I., \& Saifi, I. L. (2018). Effects of E-learning on students' academic learning at university level. The study highlights the effects of e-learning on students' academic learning at university level. The objective of the study was; to find out the effects of E-learning on students' interest and learning at university level. Researchers used quantitative research method for the study. The study found that E-learning provides time flexibility to the students and it motivates students to do their own work without others help. It 
was also that students feel comfortable when they use internet. The study concluded that elearning is a system that provide time flexibility to the students for their learning and motivates students to do their work without others help. It is also concluded that students feel comfort in browsing and surfing internet.

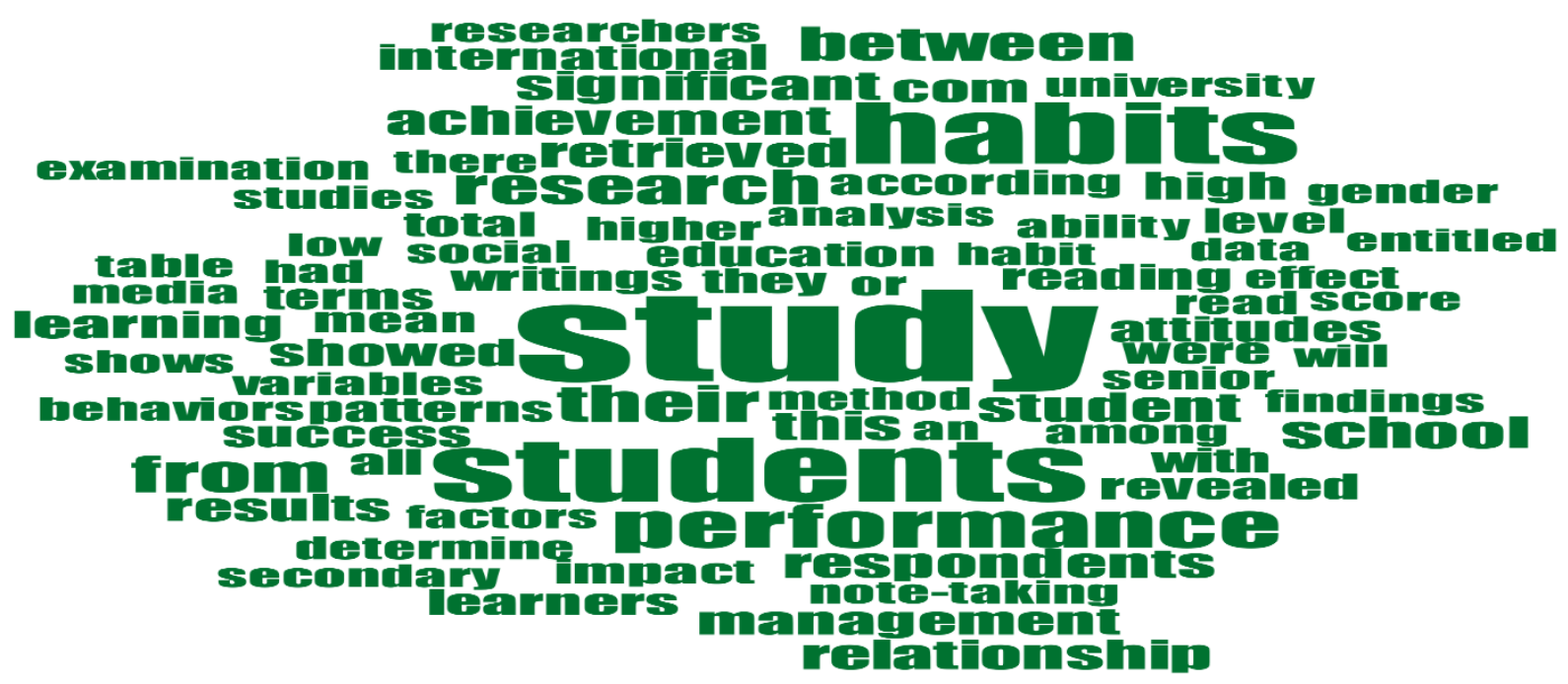

Figure 2: Showing the visual description of related review of literature Source: Maxqda Software

From the review of related literature, it is visible that most frequent concurrent word is the study habit with 73 counts, students' performance with 65 counts, note taking and reading effect 43 counts, attitude with 25 counts, impact with 20 counts. It states that positive study habits improves student's performance. Positive study habits include note taking, reading time, time management relationship etc.

\subsection{Research Gap:}

None or very limited studies have been conducted on the impact of online study habits of Ashramic school of West Bengal during Covid period. Most of the study related to online education and academic performance of students. Therefore, researcher have decided to undertake a study related to online study habits Of Secondary Ashramic Students of West Bengal during Pandemic Situation

\subsection{Statement of Problem}

The Covid has brought a new transformation all over the world. Other parts of developed countries were well accustomed with the online platform, as often they conduct online classes for the purpose of seminar, conference or the instructional one. However, the trend of online classes in traditional system of school education was not frequent. It really created weird situation for students as well as teachers. After the transitional stage school boards decided to conduct online education so that the flow of education does not get stagnant. The trend of Ashramic school was very different from the other type of public schools in West Bengal 
because the prime criteria was face-to-face relation between teacher and student. Teachers also share close bonding with students. In such school, they maintained a strict discipline, which help them to develop good study habits. However, in online education such protocols were being actually maintain and retain between them or not, is concerned interest. The problem related to "Online Study Habits of Secondary Ashramic Students of West Bengal during Pandemic Situation"

\subsection{Objective of study}

The objectives of study are:

1. To determine the mean score difference between learners in online engagement.

2. To assess the mean score difference between learners in online experience.

3. To determine the association between online study habits of learners of different locality.

4. To determine the relationship between online engagement and online learning experiences of learners.

5. To determine the relationship between online engagement and online study habits of learners.

6. To determine the relationship between online learning experiences and online study habits.

\subsection{Formulation of Hypothesis}

The hypothesis of study are as follows:

Ho1: There is no significant difference in learner's mean scores on online engagement in respect of locality.

Ho2: There is no significant difference in learner's mean scores on online experience in respect of locality.

Ho3: There exist no significant association between online study habits of learners and their locality.

Ho4: There is no significant relationship between online engagement and online learning experiences of learners.

Hos: There is no significant relationship between online engagement and online study habits of learners.

Ho6: There is no significant relationship between online learning experiences and online study habits.

\subsection{Variables of study}

The present study will highlight on the online study habit of Secondary Ashramic Students of West Bengal during Pandemic Situation". Therefore, the variables of the present study are as follows:

* Categorical Variables- Online study habit.

* Independent Variables- student engagement and learning experiences.

* Demographic Variables- locale of secondary schools (rural and urban).

* Intervening Variable- Distraction, lack of opportunities, unwillingness, lack of interest. 


\subsection{Operational Definition}

\subsubsection{Online Study Habits:}

Online study habit related with habitual practices one uses to help them to study and learn. The ability of the learner to schedule his time, the plan of the study, the habit of concentration, note taking etc., with the help of electronic media.

\subsubsection{Ashramic Students:}

Ashram schools are residential schools, which impart education up to the secondary education to children. Here students receive free boarding and lodging for pursuing education in a congenial environment.

\subsubsection{Online Engagement}

Online engagement commonly defined as the interaction between people across a range of social networks. Online engagement defined as a measure of a student's participation in the online learning process. This includes their interaction and cooperation with the teacher and classmates in an online mode.

\subsubsection{Online learning Experience}

Online learning experience refers to any interaction, course, program, or other experience in which learning takes place with the help of social networking.

\subsection{Delimitation of Study}

\subsubsection{Area}

This type of study could been conducted in any area of the state of West Bengal. However, considering the in- depthness of the study it will be conducted in the district of North 24 Parganas and South 24 Parganas, districts of West Bengal.

\subsubsection{Secondary Students Population}

This type of study could been conducted on the primary and junior secondary population belong to different public schools. However, it decided that, the study would conducted on the Secondary students of Ashramic schools of North 24 Parganas and South 24 Parganas districts of West Bengal.

\subsubsection{Conceptual Issues}

Academic achievement could been judged with reference to different concepts interlinked with it. However, in this study, levels of education, socio economic conditions and locational variations of the secondary students would been taken into account to estimate their online performance during pandemic. 


\section{Method of Data Collection}

\subsection{Area of Study}

The study conducted in the districts of West Bengal.

\subsection{Target Population}

The total number of students who were studying in Ashramic school in West Bengal in an online mode.

\subsection{Method of Data Collection}

The study made use of both primary and secondary data.

Primary data collected by applying the self-made tools of researcher and responses collected from the respondents through interviews. It refers to that data which is collected for a specific purpose from the field and are original in nature.

Secondary data collected through various web sources and expert opinion, various textbooks, websites, journals, dissertations, etc.

\subsection{Sample of the Study}

The states where larger proportions of out-migrants were enumerated are west-Bengal (21.4 per cent) To estimate the sample size Krejcie and Morgan table used. For a given infinite population of the total sample size is 201 from different schools of West Bengal, which are Ashramic in nature. To determine the sample size investigator used the Morgan's Table with 5\% error of margin at 95\% confidence level (Morgan, 1970) to justify the authenticity of selected sample size.

\subsection{Sampling Technique}

Investigator used probability-stratified sampling techniques for data collection. Data, collected from primary sources, compiled from Quantitative analysis. This technique based on three criteria, which delineated below:

- Firstly, the respondents must belong from the Ashramic schools.

- Secondly, they must belong to the West Bengal.

- Thirdly, they must be from the secondary level.

\subsection{Tools used for the study}

To conduct the study researcher will use self-made tools for measuring the dimensions of online engagement, study habits, learning experiences of secondary students of Ashramic schools.

Table 1: Demographic profile of respondents

\begin{tabular}{|c|c|c|c|}
\hline Sl.No. & Locality & No. of Respondents & Percentage \\
\hline 1 & North 24 Parganas & 101 & 50.2 \\
\hline 2 & South 24 Parganas & 100 & 49.8 \\
\hline
\end{tabular}

Source: Field Survey 


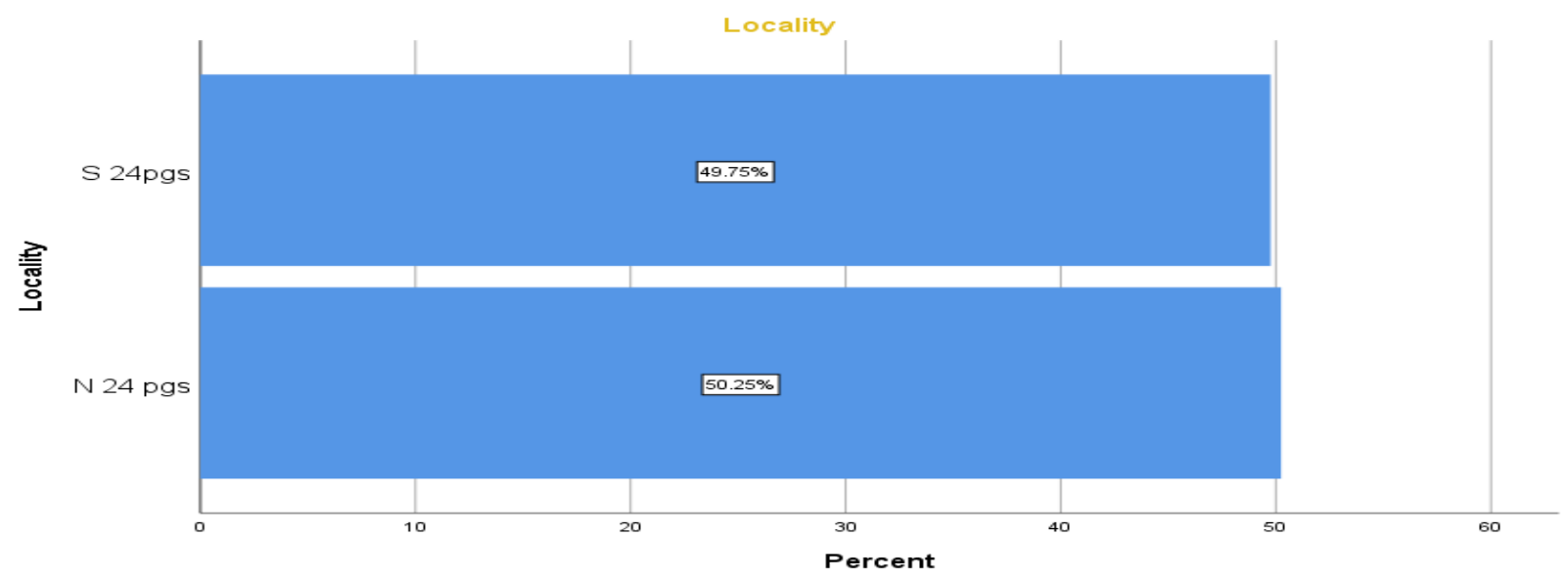

Figure 3: Showing graphical representation of demographic profile

\section{Analysis and Interpretation}

\subsection{Pertaining to hypothesis 1}

Ho1: There is no significant difference in learner's mean scores on online engagement in respect of locality.

To test the hypothesis t-test used by the investigator which showed in the table 2 .

Table 2: showing the online engagement of learners in respect of locality

\begin{tabular}{|c|c|c|c|c|c|c|}
\hline Sl.No. & Item/Variable & Locality & Mean & SD & $\begin{array}{c}\text { t- } \\
\text { Value }\end{array}$ & $\begin{array}{c}\text { Sig. } \\
\text { Value }\end{array}$ \\
\hline 1 & I can discuss my ideas freely in the & N.24 Pgs. & 1.56 & .793 & .488 & .626 \\
& class & S.24 Pgs. & 1.51 & .785 & & \\
\hline 2 & I can ask questions freely in the & N.24 Pgs. & 1.57 & 804 & .564 & .573 \\
& class & S.24 Pgs. & 1.64 & .847 & & \\
\hline 3 & Classes are engaging & N.24 Pgs. & 2.40 & .916 & 3.285 & .001 \\
& & S.24 Pgs. & 1.59 & .745 & & \\
\hline 4 & I feel motivated to attend the class & N.24 Pgs. & 2.35 & .916 & 3.289 & .001 \\
& & S.24 Pgs. & 1.76 & .745 & & \\
\hline 5 & Class discussions with other & N.24 Pgs. & 2.40 & .711 & 3.278 & .000 \\
& students & S.24 Pgs. & 2.00 & .805 & & \\
\hline 6 & Class held with practical & N.24 Pgs. & 2.38 & .791 & 2.29 & .000 \\
& experience & S.24 Pgs. & 1.79 & .916 & & \\
\hline 7 & I feel supported in the class & N.24 Pgs. & 1.56 & .792 & .488 & .626 \\
& & S.24 Pgs. & 1.51 & .714 & & \\
\hline
\end{tabular}

\section{Source: SPSS Software}

From the table 2, it is found that both the localities of students does not vary significantly in discussing ideas freely in the class with $\mathrm{t}(199)=.488$, p value is greater than 0.05 , which suggest that significant difference does not exist between the groups. Both the groups does not vary significantly in asking questions freely in the class with $t(199)=.564$, p value is greater than 
0.05, which suggest that significant difference does not exist between the groups. In classroom engaging work, the group vary significantly with $\mathrm{t}(199)=.3 .285$, p value is lesser than 0.05 , which suggest that significant difference exist between the groups. The students of north 24 Parganas feel more engaged than the south 24 Pargana with mean and S.D. $2.40 \pm .916$ and $1.59 \pm .745$ respectively. As students of north 24 Pargana feel more engaged in the class, as a result they are more motivated so the groups vary significantly with $t(199)=3.289$, p value is lesser than 0.05, which suggest that significant difference exist between the groups with leading mean with $2.35 \pm .916$, mean and S.D. In related to classroom discussion with other students both groups not vary with $\mathrm{t}(199)=.3 .278$, p value is lesser than 0.05 . The north 24 Parganas students participate more in online discussion, debates, demonstration more actively than the south one. They also gain more practical and live experiences which results in significant difference between the groups with $\mathrm{t}(199)=2.29$, $\mathrm{p}$ value is lesser than 0.05 . In relation to student support feeling in the class the group does not vary significantly with $t(199)=.488, p$ value is greater than 0.05 . This is because there are some students who stated that the students who are more active in the class teachers preference is more for them. The teacher hardly gets time to reach each students individually and conducts discussions with them separately so students who remain engaged and can follow the class they felt supported.

\subsection{Pertaining to hypothesis 2}

$\mathrm{H}_{\mathrm{o} 2}$ : There is no significant difference in learner's mean scores on online experience in respect of locality.

To test the hypothesis t-test used by the investigator, which showed in the table 3 .

Table 3: Showing the Online experience of learners in respect of locality

\begin{tabular}{|c|l|l|l|l|l|l|}
\hline Sl.No. & Item/Variable & Locality & Mean & SD & $\begin{array}{l}\text { t- } \\
\text { Value }\end{array}$ & $\begin{array}{l}\text { Sig. } \\
\text { Value }\end{array}$ \\
\hline 1 & & & & & \\
& I can get information about the course & N.24 Pgs. & 2.15 & .754 & 2.347 & .002 \\
& requirements easily. & S.24 Pgs. & 1.91 & .980 & & \\
\hline 2 & I receive timely feedback from my & N.24 Pgs. & 1.78 & .808 & .105 & .917 \\
& instructors on all the assigned work & S.24 Pgs. & 1.77 & .809 & & \\
\hline 3 & The online teaching application used & N.24 Pgs. & 1.56 & .798 & .488 & .626 \\
& in the classes is user friendly & S.24 Pgs. & 1.51 & .765 & & \\
\hline \multirow{2}{*}{4} & It is easy to meet my instructor during & N.24 Pgs. & 2.30 & .743 & 3.150 & .002 \\
& office hours & S.24 Pgs. & 1.93 & .987 & & \\
\hline 5 & It is easy to communicate with my & N.24 Pgs. & 2.45 & .756 & 2.47 & .003 \\
& instructor in synchronous sessions & S.24 Pgs. & 1.99 & .956 & & \\
\hline 6 & It is easy to communicate with other & N.24 Pgs. & 2.40 & .711 & 2.47 & .000 \\
& students in online sessions & S.24 Pgs. & 1.97 & .805 & & \\
\hline 7 & It is easy to collaborate with other & N.24 Pgs. & 2.22 & .890 & 3.657 & .002 \\
& students for group work & S.24 Pgs. & 1.94 & .893 & & \\
\hline
\end{tabular}

\section{Source: SPSS Software}


From the table 3 it is found that, both the localities of students vary significantly with $t$ (199) $=2.347$, $\mathrm{p}$ value is lesser than 0.05 , which suggest that significant difference exist between the groups in respect of getting information about the course requirements. The students of north 24 Parganas get information about the course requirements than the south 24 Pargana with mean and S.D. $2.15 \pm .754$ and $1.91 \pm .980$ respectively. In using the user-friendly online teaching application both the groups does not vary significantly with $t(199)=.488$, p value is greater than 0.05 . The students of north 24 Parganas can meet with instructor during office hours in online mode to clear their doubts. They can even clear their doubts in an online mode, which facilitates them with better online experience. So the group vary significantly with $t$ $(199)=2.47, \mathrm{p}$ value is lesser than 0.05 . They even have easy communicative sessions where the group again vary significantly with $\mathrm{t}(199)=2.47$, p value is less than 0.05 . The students of north 24 Parganas collaborate with students in-group work in compare to south 24 Parganas. So the group vary significantly with $\mathrm{t}(199)=3.657$, $\mathrm{p}$ value is lesser than 0.05 . It is because the school of north 24 Parga in recent days are taking the advantages of ICT in administrative functioning like filling up of various scholarship related forms for the students, updating school related information to the concerning authorities or maintaining of school data base including pay rolls and so on. Demonstrating various subjects using projector, or KYAN not only helps the students to understand the subject better but the teachers too. Its audiovisual impact attracts the students to be more attentive.

\subsection{Pertaining to hypothesis 3}

Ho3: The online study habits of learners is independent of locality.

To test the hypothesis t-test used by the investigator, which showed in the table 4 .

Table 4: Showing the online study habits of learners based on their locality

\begin{tabular}{|c|c|c|c|c|c|c|c|}
\hline Sl.No. & Item/Variable & Locality & Yes & Sometimes & No & $\mathrm{X}^{2}$ & Sig.Value \\
\hline 1 & $\begin{array}{l}\text { I take notes properly } \\
\text { during class. }\end{array}$ & $\begin{array}{l}\text { N.24 Pgs. } \\
\text { S.24 Pgs. }\end{array}$ & $\begin{array}{l}26 \\
12\end{array}$ & $\begin{array}{l}31 \\
39\end{array}$ & $\begin{array}{l}44 \\
49\end{array}$ & 6.336 & .042 \\
\hline 2 & $\begin{array}{l}\text { I take naps during } \\
\text { class. }\end{array}$ & $\begin{array}{l}\text { N.24 Pgs. } \\
\text { S.24 Pgs. }\end{array}$ & $\begin{array}{l}18 \\
31\end{array}$ & $\begin{array}{l}41 \\
64\end{array}$ & $\begin{array}{l}42 \\
05\end{array}$ & 37.611 & .000 \\
\hline 3 & $\begin{array}{l}\text { I look at my } \\
\text { cellphone or send } \\
\text { text messages during } \\
\text { class }\end{array}$ & $\begin{array}{l}\text { N.24 Pgs. } \\
\text { S.24 Pgs. }\end{array}$ & $\begin{array}{l}53 \\
47\end{array}$ & $\begin{array}{l}26 \\
48\end{array}$ & $\begin{array}{l}22 \\
05\end{array}$ & 17.60 & .000 \\
\hline 4 & $\begin{array}{l}\text { I read books other } \\
\text { than textbook. }\end{array}$ & $\begin{array}{l}\text { N.24 Pgs. } \\
\text { S.24 Pgs. }\end{array}$ & $\begin{array}{l}18 \\
31\end{array}$ & $\begin{array}{l}41 \\
64\end{array}$ & $\begin{array}{l}42 \\
05\end{array}$ & 37.611 & .000 \\
\hline 5 & $\begin{array}{l}\text { I space out during } \\
\text { class. }\end{array}$ & $\begin{array}{l}\text { N.24 Pgs. } \\
\text { S.24 Pgs. }\end{array}$ & $\begin{array}{l}61 \\
52\end{array}$ & $\begin{array}{l}26 \\
38\end{array}$ & $\begin{array}{l}10 \\
10\end{array}$ & 21.253 & .000 \\
\hline 6 & $\begin{array}{l}\text { I actively participate } \\
\text { in group work }\end{array}$ & $\begin{array}{l}\text { N.24 Pgs. } \\
\text { S.24 Pgs. }\end{array}$ & $\begin{array}{l}30 \\
09\end{array}$ & $\begin{array}{l}11 \\
40\end{array}$ & $\begin{array}{l}56 \\
51\end{array}$ & 31.255 & .000 \\
\hline 7 & $\begin{array}{l}\text { I finish homework on } \\
\text { time. }\end{array}$ & $\begin{array}{l}\text { N.24 Pgs. } \\
\text { S.24 Pgs. }\end{array}$ & $\begin{array}{l}26 \\
12\end{array}$ & $\begin{array}{l}31 \\
39\end{array}$ & $\begin{array}{l}44 \\
49\end{array}$ & 6.336 & .042 \\
\hline
\end{tabular}




\begin{tabular}{|l|l|l|l|l|l|l|l|}
\hline 8 & $\begin{array}{l}\text { I prepare for classes } \\
\text { beforehand } \begin{array}{l}\text { N.24 Pgs. } \\
\text { review what I have } \\
\text { learned. }\end{array}\end{array}$ & $\begin{array}{l}26 \\
\text { S.24 Pgs. }\end{array}$ & $\begin{array}{l}31 \\
39\end{array}$ & $\begin{array}{l}44 \\
49\end{array}$ & 6.336 & .042 \\
\hline 9 & $\begin{array}{l}\text { I actively study } \\
\text { without told at } \\
\text { home. S.24 Pgs. }\end{array}$ & 31 & 64 & 5 & 37.611 & .000 \\
\hline 10 & $\begin{array}{l}\text { I take permission of } \\
\text { instructor during } \\
\text { class for excusing } \\
\text { for a while. }\end{array}$ & S.24 Pgs. & 1 & 26 & 74 & 11.377 & .078 \\
\hline
\end{tabular}

Source: SPSS Software

From the table 4 it is found that, in respect of online habits for taking notes during the class there is significant difference between the groups with $X^{2}$ value $=6.336$ and $p$ value .042 . the students from south 24 Parganas are more fond of taking nap during their class so both the groups vary significantly with $X^{2}$ value $=37.611$ and $p$ value .000 . The group vary in respect of in respect of looking at their cellphone or send text messages during class with $\mathrm{X}^{2}$ value $=$ 17.60 and $\mathrm{p}$ value .000 . In respect of reading books other than textbook the group vary significantly with $\mathrm{X}^{2}$ value $=37.611$ and $\mathrm{p}$ value .000 . During the class they even space out in their home rooms, which indicates that they devoid the classroom mannerism and habits which is found significantly within the groups where $X^{2}$ value $=21.253$ and $p$ value .000 . When the individuals feel motivated and interested they will actively participate in-group work. The learners differ significantly in respect of group with $\mathrm{X}^{2}$ value $=31.255$ and $\mathrm{p}$ value .000 . The group vary significantly in respect of completion of homework on time with $\mathrm{X}^{2}$ value $=6.336$ and $\mathrm{p}$ value .042 . The students from north 24 Parganas mostly prepare for classes beforehand and review what they have learned as because their online activities occur more frequently, so the group vary significantly with $\mathrm{X}^{2}$ value $=6.336$ and $\mathrm{p}$ value .042 . The students of north locality more punctual in respect of studying in home without being told by their caregivers so the group vary significantly with $\mathrm{X}^{2}$ value $=37.611$ and $\mathrm{p}$ value .000 . Only in case of taking permission of instructor during class for excusing for a while both the group does not vary significantly with $\mathrm{X}^{2}$ value $=11.377$ and $\mathrm{p}$ value .078 . It is because both the group switch off their videos on the time of excusing themselves from the online class.

\subsection{Pertaining to hypothesis 4}

Ho4: There is no significant relationship between online engagement and online learning experiences of learners.

To test the hypothesis t-test used by the investigator, which showed in the table 5 . 
Table 5: Showing the online study habits of learners based on their locality

\begin{tabular}{|c|c|c|c|c|}
\hline & & $\begin{array}{c}\text { Online } \\
\text { Engagement }\end{array}$ & $\begin{array}{c}\text { Online Learning } \\
\text { experience }\end{array}$ & $\begin{array}{c}\text { Online } \\
\text { Study } \\
\text { Habits }\end{array}$ \\
\hline \multirow[t]{3}{*}{ Online Engagement } & Pearson Correlation & 1 & $.873^{* * *}$ & .718 \\
\hline & Sig. (2-tailed) & & .000 & .000 \\
\hline & $\mathrm{N}$ & 201 & 201 & 201 \\
\hline \multirow{3}{*}{$\begin{array}{l}\text { Online Learning } \\
\text { experience }\end{array}$} & Pearson Correlation & $.873^{* *}$ & 1 & $.821^{*}$ \\
\hline & Sig. (2-tailed) & .000 & & .048 \\
\hline & $\mathrm{N}$ & 201 & 201 & 201 \\
\hline \multirow[t]{3}{*}{ Online Study Habits } & Pearson Correlation & .718 & .821 & 1 \\
\hline & Sig. (2-tailed) & .000 & .048 & \\
\hline & $\mathrm{N}$ & 201 & 201 & 201 \\
\hline
\end{tabular}

From the table 5, it displayed that, the correlation between the variables are highly positive. The highest correlation found between online engagement and online learning experience $(\mathrm{r}=.873)$. So positive relationship prevails between variables. The online student engagement particularly influenced by a sense of belonging to the institutional, programme and module community. The two factors that can support the development of a sense of community and belonging in students are establishing social presence and high levels of interaction in the course. Developing social presence in the course gives students a greater sense of connection to each other, the teacher and the course. Interaction and social presence promoted through course design, which promotes active communication between students and instructors using asynchronous discussion forums and synchronous online classes. The more the students are engaged in the online mode the more positive online experience develop between them.

\subsection{Pertaining to hypothesis 5}

Hos: There is no significant relationship between online engagement and online study habits of learners.

From the table 5, it displayed that, the correlation between the variables are highly positive. The correlation found between online engagement and online study habits of learner is positively related $(\mathrm{r}=.718)$. This engagement give them positive motivation and train them in self-discipline. In having study habits like Time Scheduling, Concentration, Listening and Note taking, hence, found in learners, which help them to connect with the course module. The more the students are engaged in the online mode the more positive healthy habits develop between them. 


\subsection{Pertaining to hypothesis 6}

Ho6: There is no significant relationship between online learning experiences and online study habits

From the table 5, it displayed that, the correlation between the variables are highly positive. The correlation found between online learning experience and online study habits of learner is positively related $(\mathrm{r}=.821)$. Students who have positive experiences are more likely to reenroll in online courses in the future, so an institution that seeks to increase online enrollment would benefit from such information. Data about student experiences also can provide information to help institutions and faculty design and deliver better courses, which could help improve student learning in these courses. Such data also could help institutions and faculty to determine what challenges students face in online mode, which could in turn improve persistence and retention in online courses. The more the students are getting positive experiences in the online mode the more positive healthy habits develop between them.

\section{Conclusion}

From the above discussion, it concluded that online study habit has a profound impact on learning experience and online engagement. The school authorities need to design and plan course in a systematic way. Students should have good opportunities to connect with peers and teachers in online discussion, debates, symposium, pairing activities etc., It is not only with presenting the content in online platform and completing the course content by touching the shreds of content. However, most importantly using the ICT in a judicious way by presenting the content meaningfully, into different sections. Each section of the sub content meaningfully related in a sequence manner, so that they find the content meaningful. Instructors also had a strong influence over student experience, in large part through their accessibility and through their efforts to provide opportunities to connect with peers. Unfortunately, not all students had positive experiences with their instructors, and thus their online experiences suffered. Students who lacks positive study habits guidance and counselling services on the formation of good study habits need to be organize during their orientation programme on the start of their enrolment into the online programme.

\section{Reference}

- Akdemir, O., \& Koszalka, T. A. (2008). Investigating the relationships among instructional strategies and learning styles in online environments. Computers \& Education, 50(4), 14511461.

- Akkoyunlu, B., \& Soylu, M. Y. (2008). A study of student's perceptions in a blended learning environment based on different learning styles. Educational Technology \& Society, 11(1), 183193.

- Allen, M., J. Bourhis, N. Burrell, \& E. Mabry. (2002). Comparing student satisfaction with distance education to traditional classrooms in higher education: A met analysis. The American Journal of Distance Education, 16(2), 83-97.

- Ally, M., \& Fahy, P. (2002, August). Using students' learning styles to provide support in distance education. In Proceedings of the Eighteenth Annual Conference on Distance Teaching and Learning, Madison, WI. 
- Aragon, S. R., Johnson, S. D., \& Shaik, N. (2002). The influence of learning style preferences on student success in online versus face-to-face environments. The American Journal of Distance Education, 16(4), 227-243.

- Aşkar, P., \& Akkoyunlu, B. (1993). Kolb learning style inventory. Education and Science, 15 (81), 37-47.

- Benbunan-Fich, R., \& S. R. Hiltz. (2003). Mediators of the effectiveness of online courses. IEEE Transactions on Professional Communication, 46(4), 298-312.

- Chen, N. S., \& Lin, K. M. (2002, September). Factors affecting e learning for achievement. In IEEE International Conference on Advanced Learning Technologies (9-12).

- Coffield, F., Moseley, D., Hall, E., \& Ecclestone, K. (2012). Learning styles and pedagogy in post-16 learning: A systematic and critical review. Learning and Skills Research Centre: London.

- Cohen, J. (1988). Statistical power analysis for the behavioral sciences (2nd ed.) Hillsdale, NJ: Lawrence Erlbaum Associates.

- Coleman, P., Collinge, J., \& Tabin, Y. (1993). The Learning triad: Parental involvement. London: University of North London Press.

- Crede, M., \& Kuncel, N. R. (2008). Study habits, skills, and attitudes: The third pillar supporting collegiate academic performance. Perspectives on Psychological Science, 3, 425454. 